\title{
Evaluation of Different Cropping Systems for Marginal Uplands in Inopacan, Leyte
}

\author{
Ed Allan L. Alcober ${ }^{1}$, Melanie D. Ratilla', Othello B. Capuno ${ }^{2}$ \\ and Jorge S. Valenzona ${ }^{3}$
}

${ }^{1}$ Department of Agronomy and Soil Science, Visayas State University ${ }^{2}$ Office of the Vice President for Research and Extension, Visayas State University, ${ }^{3}$ Department of Mathematics, Physics and Statistics, Visayas State University

\begin{abstract}
Low crop productivity in most marginal uplands is primarily due to poor agro-ecological conditions. There is a need to improve farming practices of upland farmers to improve their quality of life thus, the study was conducted in the marginal uplands of Brgy. Linao, Inopacan, Leyte, Philippines from February to July 2013, to determine the best cropping system that would improve crop productivity and to promote the best cropping system technology to upland farmers. The experimental units were arranged in Randomized Complete Block Design with three replications. The treatments were intercropping (upland rice + mungbean, corn + mungbean) and monocropping (upland rice, corn and mungbean). The growth and yield parameters were not significantly influenced by the cropping systems. Thus, crop growth and development in either intercropping or monocropping schemes were comparable. However, corn + mungbean gave a land equivalent ratio (LER) of 1.53, which means that such cropping system is more productive than growing corn or mungbean as monocrop. On the other hand, growing upland rice alone was more productive than upland rice + mungbean as indicated by a LER of 0.93 . Corn + mungbean gave a net income of PhP 8,452.18 per hectare.
\end{abstract}

Keywords: intercropping, monocropping, land equivalent ratio, area time equivalent ratio 
Evaluation of different cropping systems for marginal uplands

\section{INTRODUCTION}

Of the 30 million hectares total land area of the Philippines upland comprise about 14.9 \% (Tacio, 2005 as cited by Castillo, 2010). In Eastern Visayas, degraded uplands are vast, occupying about 362,123.02 hectares (Tejada et al., 2008). These land resources are unproductive and underutilized because of poor soil conditions thus most agronomic and horticultural crops cannot grow productively. According to Macandog et al. (2006), marginal uplands are acidic, low in organic matter content, and low in nitrogen, phosphorus and potassium elements. Thus, most of these lands remain idle for years and do not contribute to the agriculture's economic aspect.

In the early 1990's, marginal uplands were unpopulated. Now, these lands are mostly inhabited by resource poor farmers having an average annual income of PhP2,168.00 (Guerrero, 2000 as cited by Castillo, 2010 ). Farming is their primary livelihood, but it is not enough to alleviate their economic condition. Gerpacio et al. (2004) found that the average yield of traditional corn varieties in the upland ranged from 1.0 to $2.0 \mathrm{t} / \mathrm{ha}$; while in rainfed environment, rice produces an average of $1 \mathrm{t} / \mathrm{ha}$ (IRRI, n.d.). Low production is attributed to sub optimal fertilization, extended drought period, capital constraints, pests, and lack of information on high-yielding crop varieties. Moreover, the present cropping system has made these farmers over dependent on their traditional practices. For instance, upland farmers in Inopacan plant only once a year (June-July) because water is so scarce in the other months; therefore, time and land utilization is not maximized; crop productivity and profitability is not attained. Identification of appropriate cropping system and improve production practices could potentially make marginal upland farming productive and profitable activity.

Cropping system comprises all farming practices and technologies that a farmer adopts relative to the present needs and condition of the farm. This includes the yearly sequence of crops and spatial arrangement of crops on a given year (Escasinas, 1990). One farming strategy to improve productivity is farm diversification through multiple cropping system. Multiple cropping is practically applicable for subsistence farmers whose farms are small and resources are limited (PCARR, 1976). This system promotes farm diversity, and enhances farm stability and efficiency in the use of land and labor; thus, land productivity per unit time is maximized (Cantoneros, 2008). Environmental resources such as light, water and soil 
nutrients are capitalized for plant growth (Azam-ali et al., 1990); and weed density and soil erosion are better controlled because of leaf canopy closure. In Indonesia, the combination of cereals and legumes (maize + soybean - maize + peanut - mungbean) proved to be the best in upland farming providing greater yields in terms of calories, protein, and cash income (Adiningsih and Karama, 1998). Carandang (1976) reported that intercropping corn with legumes increased productivity of the farm by 20 to $60 \%$ which was attributed to the biological nitrogen fixation by legumes that provided extra nitrogen for the corn plants.

For crop diversification to be productive and sustainable, several factors such as agronomic characteristics of the complementary crops, soil and climatic conditions and available farm resources should be thoroughly evaluated. Thus, this study was conducted to determine the best cropping system that would improve crop productivity, and promote the best cropping system technology under marginal upland conditions.

\section{MATERIALS AND METHODS}

\section{Site Description}

The experiment was conducted in Sitio Batuan, Brgy. Linao, Inopacan, Leyte. Sitio Batuan is a mountainous area situated approximately 8 kilometers away from the town of Inopocan, Leyte. Vegetation dominated by Cogon grass (Imperata cylindrica) are growing on uncultivated areas. The most common crops grown by farmers are coconut, cassava, corn, upland rice, mungbean and peanut. The area was selected as the research site because of the following reasons: (1) large area is characterized as acid upland and (2) low productivity of agronomic crops attributed mainly to (a) soil erosion and infertility, (b) weeds, and (c) drought; which offer opportunities for research to increase land productivity.

The experimental area was owned by a farmer who started tilling the land when he was at his prime age. He planted upland rice, peanut, corn and mungbean once a year on rotational basis. When he was about to stop farming, he planted perennial crops like mangoes and dwarf coconuts.

The site was left unproductive for 18 years before the experiment was established. Mangoes and dwarf coconuts existed, competing with Saccharum spontaneum., Imperata cylindrica, Chromolaena odorata and other upland grasses (Fig 1). The growth of the perennial crops was 
Evaluation of different cropping systems for marginal uplands

stunted and the leaves were yellow which manifest that the crops were deficient of essential nutrients.

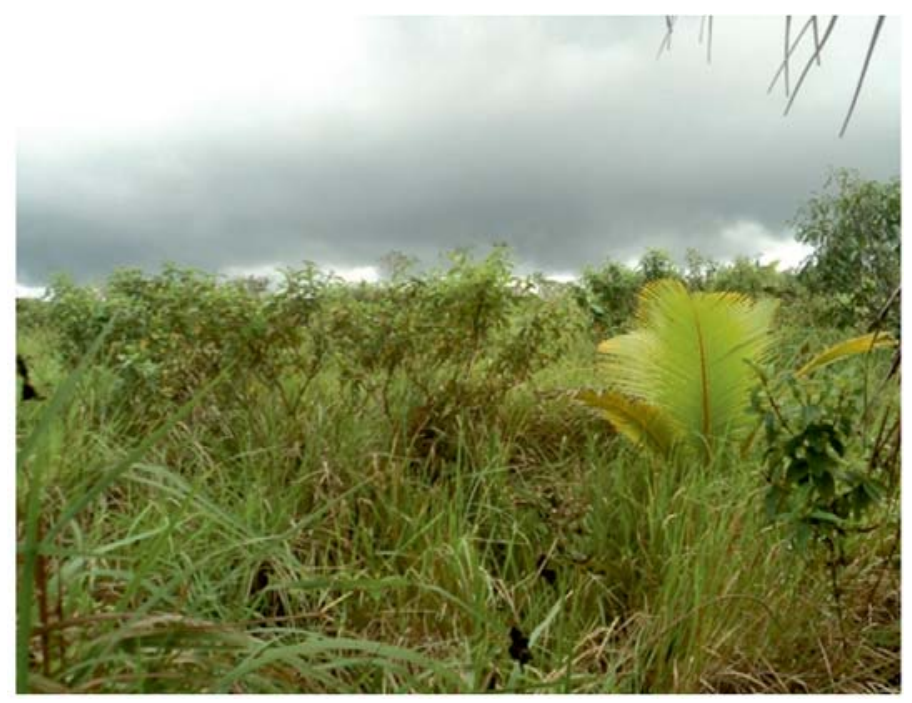

Figure 1. Experimental site after being idle for 18 years

\section{Experimental setup and establishment}

An area of $400 \mathrm{~m}^{2}$ was cleared to allow land cultivation. The land was plowed five times to break the hard pan and harrowed twice to pulverize the soil clods. Weed herbages were piled up and allowed to decompose.

Before planting, 10 core soil samples were randomly collected from the experimental area at a depth of $0-20 \mathrm{~cm}$. These samples were composited, air dried, sieved (2 $\mathrm{mm}$ wire mesh) and analyzed for soil $\mathrm{pH}$ (potentiometric method at 1:2.5 soil water ratio), organic matter (modified Walkley- Black method), total N (modified Kjeldahl method), available phosphorous (modified Olsen's method) and exchangeable $\mathrm{K}$ (ammonium acetate method $\mathrm{pH} 7.0$ for extraction and were quantified by using Varian 220 FS Atomic Absorption Spectrometer) at the Central Analytical Services Laboratory (CASL) of PhilRootcrops, Visayas State University. Soil samples from the same treatment plots were also collected at harvest and analyzed for the same aforementioned soil parameters.

The experiment was laid out in randomized complete block design (RCBD) with three replications and five treatments. Except for the corn 
monoculture plot which measured $5 \mathrm{~m} \times 4.5 \mathrm{~m}$, the other plots of $5 \mathrm{~m} \times 4 \mathrm{~m}$ in size. There were 6 rows per plot. Alleyways of $0.5 \mathrm{~m}$ between replication and $0.5 \mathrm{~m}$ between treatments were provided to facilitate farm operation and management as well as data gathering. The treatments were designated as follows: $\mathrm{T}_{1}=$ Corn alone; $\mathrm{T}_{2}=$ Mungbean alone; $\mathrm{T}_{3}=$ Upland Rice alone; $\mathrm{T}_{4}=$ Corn + Mungbean; $\mathrm{T}_{5}=$ Upland Rice + Mungbean.

Each treatment plot was applied with chicken manure at planting at the rate of $5 \mathrm{t} / \mathrm{ha}$ by broadcasting them along the furrows. Half of the required inorganic fertilizer (90-60-60 kg N, $\mathrm{P}_{2} \mathrm{O}_{5}, \mathrm{~K}_{2} \mathrm{O} / \mathrm{ha}$ ) was applied immediately in corn before planting by broadcasting and incorporating into the soil. The other half of inorganic fertilizer was topdressed 30 days after transplanting. Full amount of inorganic fertilizer was applied in mungbean based on the recommendation (30-30-30 kg N, $\mathrm{P}_{2} \mathrm{O}_{5}, \mathrm{~K}_{2} \mathrm{O} / \mathrm{ha}$ ). For upland rice, $50 \%$ of the $\mathrm{N}$ recommendation and full amount of the $\mathrm{K}$ and $\mathrm{P}$ were applied before planting at the recommended rate of 80-60-30 kg N, $\mathrm{P}_{2} \mathrm{O}_{5}$, $\mathrm{K}_{2} \mathrm{O} /$ ha. The other half of $\mathrm{N}$ requirement was applied during panicle initiation. The inorganic fertilizers used were complete (14-14-14), urea (46-0-0) and solophos (0-20-0).

Corn (IPB Var. 6) seeds for the monoculture treatment was sown at a distance of $0.75 \mathrm{~m}$ between rows and $0.50 \mathrm{~m}$ between hills. Two to three seeds were planted per hill which were thinned to two plants per hill one week after sowing to satisfy the desired plant population of 53,333 plants/ha. Simultaneously, mungbean (Pagasa 19), and upland rice (Zambales) seeds were drilled and thinned two weeks after planting at 20 plants/linear meter and 80 plants/ linear meter, respectively. Replanting of missing hills was also done one week after planting to meet the desired plant population.

Hilling up was done manually in each treatment plot. Weeds were controlled by hand weeding and cultivation for better stability and anchorage of the plants. For upland rice, spraying of Lannate was done at heading stage to control rice bugs.

Harvesting was done at maturity when husk and leaves changed from green to brown, the grains became firm and clear and the scutellum of the kernels darkened. Only plants from the four inner rows excluding end hills were harvested. Harvested corn ears were dehusked, sun-dried and shelled after which the grains were sundried again before gathering the subsequent data.

For mungbean, harvesting was done by priming. The first priming was made when the pods turned brown or black, leaves had begun to dry 
Evaluation of different cropping systems for marginal uplands

and defoliate, and grains became firm. Harvesting was done twice at seven days interval. For upland rice, harvesting was done when approximately $90 \%$ of grains in each plot had ripened as indicated by amber color and firmness of the grains. The panicles from the harvestable area were cut at the base of the panicle (approximately $30 \mathrm{~cm}$ ) with a sharp sickle. All the panicles in the harvestable area were threshed, cleaned and sundried. After which the grains were cleaned by winnowing before gathering the necessary data.

The following agronomic characteristics were evaluated in corn (maincrop): number of days from seeding to emergence, tasseling, silking and maturity; plant height (cm); leaf area index (LAI) and fresh stover yield $\left(\mathrm{t} \mathrm{ha}^{-1}\right)$. For the yield and yield components, the following parameters were measured: number of ears per plant; ear length $(\mathrm{cm})$; weight $(\mathrm{g})$ of 1,000 seeds; and grain yield ( $\left.\mathrm{t} \mathrm{ha}{ }^{-1}\right)$. Other parameters evaluated were: land equivalent ratio (LER) and area time equivalent ratio (ATER).

For upland rice, the following agronomic characteristics were determined: number of days from sowing to heading and maturity; plant height $(\mathrm{cm})$ at maturity and leaf area index (LAI). For the yield and yield components, the following parameters were measured: number of filled grains per panicle; percentage filled spikelet per panicle; weight (g) of 1,000 grains; grain yield ( $\mathrm{tha}^{-1}$ ) and harvest index.

The following agronomic characteristics were evaluated for mungbean (intercrop): number of days from seeding to flowering and maturity; plant height $(\mathrm{cm})$ at harvest; leaf area index (LAI) and herbage yield ( $\mathrm{t}$ ha ${ }^{-1}$ ). For the yield and yield components, the following parameters were measured: number of pods per plant; number of seeds per pod; weight (g) of 1,000 grains and grain yield ( $\left.\mathrm{t} \mathrm{ha}^{-1}\right)$. Harvest index was calculated as the ratio of the economic yield and biological yield. Initial and final soil analyses and production cost and return analysis were also done.

\section{RESULTS AND DISCUSSIONS}

\section{Generalobservation}

Establishing a farm left idle for 18 years is labor-intensive, timeconsuming and expensive. The time and labor requirement were doubled in order to clear the land and prepare the soil for planting. 
Water scarcity was the primary problem in the area; however, planting twice a year is possible considering the choice of crop and the timing of planting. Among the agronomic crops planted, upland rice was better than corn in terms of drought tolerance. Mungbean plants were very sensitive to drought which stunted their growth and aborted their flowers. Planting corn or upland rice during the $1^{\text {st }}$ up to the $2^{\text {nd }}$ week of February is recommended because of the occurrence of occasional rain which can still support germination. With this time frame, the grain development stage of upland rice and corn will not coincide with the peak of the drought season which is in March and early April (Table 1.)

Table 1. Total weekly rainfall $(\mathrm{mm})$ and average daily air temperature $\left({ }^{\circ} \mathrm{C}\right.$ minimum and maximum) throughout the duration of the study from February 1 to June 17, 2013 obtained from PAGASA Station, VSU, Visca, Baybay City, Leyte ( $1^{\text {st }}$ cropping).

\begin{tabular}{lccc}
\hline \multicolumn{1}{c}{ Weeks } & Rainfall $(\mathrm{mm})$ & \multicolumn{2}{c}{ Temperature $\left({ }^{0} \mathrm{C}\right)$} \\
& & Maximum & Minimum \\
\hline February 1-7 & 0.37 & 31.4 & 24.2 \\
February 8-14 & 0.87 & 31.5 & 24.3 \\
February 15-21 & 225.2 & 31.1 & 24.3 \\
February 22-28 & 128.6 & 31.2 & 24.2 \\
March 1-11 & 8.4 & 31.4 & 27.8 \\
March 12-18 & 0.7 & 30.5 & 23.7 \\
March 19-25 & 1.2 & 30.5 & 23.3 \\
March 26-April 1 & 4.6 & 30.2 & 23.5 \\
April 2-8 & 2.7 & 30.6 & 23.7 \\
April 9-15 & 0.3 & 30.4 & 23.8 \\
April 16-22 & 3.8 & 30.0 & 23.2 \\
April 23-April 29 & 0.0 & 31.2 & 24.1 \\
April 30-May 6 & 0.2 & 31.3 & 24.1 \\
May 7-May 13 & 6.2 & 30.3 & 23.3 \\
May 14-20 & 0.0 & 30.7 & 23.8 \\
May 21-27 & 1.3 & 30.0 & 23.0 \\
May 28-June 3 & 0.8 & 30.3 & 23.4 \\
June 4-10 & 5.6 & 30.1 & 23.2 \\
June 11-17 & 13.2 & 30.1 & 23.1 \\
\hline TOTAL & 526.8 & 581.5 & 456.3 \\
\hline MEAN & 27.8 & 30.6 & 24.0 \\
\hline
\end{tabular}


Evaluation of different cropping systems for marginal uplands

Insect pests and diseases were not problematic in corn and mungbean. For upland rice, Oebalus pugnax (rice stink bug) infestation and Lonchura mallaca (maya birds) which fed on rice grains were among the destructive pests. Rice bug infestation was controlled by carbamate insecticide application (Lannate). Bird infestation was not effectively controlled even if plastic strips were installed on top of the rice plants. Apparently, the birds were not scared anymore of the plastic strips. Further damage was managed by assigning a laborer to drive away the birds.

\section{Soil chemical analysis}

Initial soil analysis showed that the experimental area had a soil $\mathrm{pH}$ of 4.83 , with $2.17 \%$ organic matter, $0.27 \%$ total $\mathrm{N}, 1.18 \mathrm{mg} / \mathrm{kg}$ available $\mathrm{P}$ and $0.20 \mathrm{mg} / \mathrm{kg}$ exchangeable $\mathrm{K}$ (Table 2). These indicate that the soil is strongly acidic, low in organic matter, and very deficient in nitrogen, available $P$ and exchangeable K (Landon, 1991).

The result of the final soil analysis did not vary relative to the initial soil analysis. It appears that the application of chicken dung (5 t/ha) before planting did not influence the chemical properties of the soil. According to Edmeades (2003), manures may only have a benefit on soil productivity, when applied sequentially for a period of time. This suggests continuous application of manures every cropping in marginal uplands to improve and sustain soil fertility.

Table 2. Initial and final soil analyses of the experimental area as affected by different cropping systems.

\begin{tabular}{lccccc}
\hline & Soil pH & $\mathrm{OM}(\%)$ & $\begin{array}{c}\text { Total } \\
\mathrm{N}(\%)\end{array}$ & $\begin{array}{c}\text { Available } \\
\mathrm{P}(\mathrm{mg} / \mathrm{kg})\end{array}$ & $\begin{array}{c}\text { Exchangeable } \\
\mathrm{K}(\mathrm{mg} / \mathrm{kg})\end{array}$ \\
\hline Initial Soil Analysis & 4.83 & 2.17 & 0.27 & 1.18 & 0.20 \\
\hline Final Soil Analysis & & & & & \\
Corn & & & & & \\
Monocropping & 4.96 & 1.86 & 0.24 & 1.87 & 0.16 \\
Intercropping & 4.99 & 1.77 & 0.25 & 1.48 & 0.16 \\
\hline Upland Rice & & & & & \\
Monocropping & 4.97 & 2.37 & 0.27 & 1.22 & 0.21 \\
Intercropping & 4.90 & 2.33 & 0.26 & 2.22 & 0.24 \\
\hline Mungbean & & & & & \\
& & & & & 0.19 \\
Monocropping & 4.97 & 1.47 & 0.23 & 2.10 & 0.16 \\
Intercropping & 4.99 & 1.77 & 0.25 & 1.48 & \\
\hline
\end{tabular}




\section{Agronomic characteristics and yield and yield components}

The growth and yield of the main crops: upland rice and corn were not significantly influenced by cropping system (Tables 3-8). This implies that these cereal crops can be comparably grown in an intercropping or monocropping system in the marginal uplands of Inopacan. In the intercropping scheme, corn (IPB var. 6) yielded $2.47 \mathrm{t} /$ ha (Table 6), better than the yield of corn documented by Gerpacio et al. (2004) that produced 1-2 t/ha only under marginal upland condition. On the other hand, the Zambales upland rice grew normally despite the off-season planting where it encountered long drought period during the early vegetative stage. At the ripening stage, large populations of Lonchura mallaca birds were observed feeding on the grains. In spite of putting plastic strips on top of the plots, the infestation was not minimized. Because of that, the upland rice only produced $0.58 \mathrm{t} / \mathrm{ha}$ (intercropping) and $0.64 \mathrm{t} / \mathrm{ha}$ (monocropping); which is less than $40 \%$ of the average yield ( $1 \mathrm{t} / \mathrm{ha}$ ) of upland rice recorded by IRRI.

Table 3.Agronomic characteristics of corn under monocropping and intercropping system

\begin{tabular}{lccc}
\hline Treatments & $\begin{array}{c}\text { Days from } \\
\text { seeding to } \\
\text { maturity }\end{array}$ & $\begin{array}{c}\text { Plant } \\
\text { Height } \\
(\mathrm{cm})\end{array}$ & $\begin{array}{c}\text { Leaf } \\
\text { Area } \\
\text { Index }\end{array}$ \\
\hline Monocropping (Corn Alone) & 96.00 & 192.50 & 1.19 \\
Intercropping (Corn + Mungbean) & 94.00 & 170.20 & 1.14 \\
\hline C.V. $(\%)$ & 1.97 & 3.98 & 13.54 \\
\hline
\end{tabular}

Table 4.Agronomic characteristic of upland rice under monocropping and intercropping system

\begin{tabular}{lcc}
\hline \multicolumn{1}{c}{ Treatments } & $\begin{array}{c}\text { Plant } \\
\text { Height } \\
(\mathrm{cm})\end{array}$ & $\begin{array}{c}\text { Leaf } \\
\text { Area } \\
\text { Index }\end{array}$ \\
\hline Monocropping (Upland Rice) & 0.22 & 7.92 \\
Intercropping (Upland Rice + Mungbean) & 0.21 & 8.41 \\
\hline C.V. $(\%)$ & 1.02 & 3.24 \\
\hline
\end{tabular}


Evaluation of different cropping systems for marginal uplands

Table 5. Agronomic characteristics of mungbean under monocropping and intercropping system

\begin{tabular}{lccc}
\hline \multicolumn{1}{c}{ Treatments } & $\begin{array}{c}\text { Plant } \\
\text { Height } \\
(\mathrm{cm})\end{array}$ & $\begin{array}{c}\text { Leaf } \\
\text { Area } \\
\text { Index }\end{array}$ & $\begin{array}{c}\text { Herbage } \\
\text { Yield } \\
\left(\mathrm{t} \mathrm{ha}^{-1}\right)\end{array}$ \\
\hline Monocropping (Mungbean Alone) & 41.47 & 0.76 & 3.63 \\
Intercropping (Corn + Mungbean) & 47.37 & 0.68 & 4.38 \\
$\mathrm{~T}_{3}=$ Intercropping (Upland Rice + Mungbean) & 45.10 & 0.72 & 4.74 \\
\hline C.V. $(\%)$ & & & \\
\hline
\end{tabular}

Table 6. Yield and yield components of corn under monocropping and intercropping system

\begin{tabular}{lccccc}
\hline \multicolumn{1}{c}{ Treatments } & $\begin{array}{c}\text { Number } \\
\text { of ears } \\
\text { per plant }\end{array}$ & $\begin{array}{c}\text { Ear } \\
\text { Length } \\
(\mathrm{cm})\end{array}$ & $\begin{array}{c}\text { Weight } \\
(\mathrm{g}) \text { of } \\
1,000 \\
\text { Seeds }\end{array}$ & $\begin{array}{c}\text { Grain } \\
\text { Yield } \\
\left(\mathrm{t} \mathrm{ha}^{-1}\right)\end{array}$ & $\begin{array}{c}\text { Harvest } \\
\text { Index }\end{array}$ \\
\hline Monocropping (Corn Alone) & 2.13 & 15.44 & 300.00 & 2.00 & 0.64 \\
Intercropping (Corn + Mungbean) & 2.47 & 14.31 & 296.67 & 2.38 & 0.58 \\
\hline C.V. (\%) & 4.22 & 9.28 & 1.37 & 5.90 & 7.33 \\
\hline
\end{tabular}

Table 7. Yield and yield components of upland rice under monocropping and intercropping system

\begin{tabular}{lcccc}
\hline \multicolumn{1}{c}{ Treatments } & $\begin{array}{c}\text { Number } \\
\text { of filled } \\
\text { grains } \\
\text { per } \\
\text { panicle }\end{array}$ & $\begin{array}{c}\text { Weight } \\
\text { of }(\mathrm{g}) \\
1,000 \\
\text { Seeds }\end{array}$ & $\begin{array}{c}\text { Grain } \\
\text { Yield } \\
\left(\mathrm{t} \mathrm{ha}^{-1}\right)\end{array}$ & $\begin{array}{c}\text { Harvest } \\
\text { Index }\end{array}$ \\
\hline Monocropping (Upland Rice Alone) & 64.33 & 48.33 & 0.64 & 0.32 \\
Intercropping (Upland Rice + Mungbean) & 77.67 & 48.00 & 0.52 & 0.33 \\
\hline C.V. $(\%)$ & 8.10 & 0.84 & 8.08 & 1.32 \\
\hline
\end{tabular}


Table 8. Yield and yield components of mungbean under monocropping and intercropping system

\begin{tabular}{lccccc}
\hline \multicolumn{1}{c}{ Treatments } & $\begin{array}{c}\text { Number } \\
\text { of pods per } \\
\text { plant }\end{array}$ & $\begin{array}{c}\text { Number } \\
\text { of seeds } \\
\text { per pod }\end{array}$ & $\begin{array}{c}\text { Weight } \\
(\mathrm{g}) \text { of } \\
1,000 \\
\text { Seeds }\end{array}$ & $\begin{array}{c}\text { Grain } \\
\text { Yield } \\
\left(\mathrm{t} \mathrm{ha}^{-1}\right)\end{array}$ & $\begin{array}{c}\text { Harvest } \\
\text { Index }\end{array}$ \\
\hline $\begin{array}{l}\text { Monocropping } \\
\text { (Mungbean Alone) }\end{array}$ & 10.73 & 10.20 & 65.93 & 0.22 & 0.37 \\
$\begin{array}{l}\text { Intercropping (Corn } \\
+ \text { Mungbean) }\end{array}$ & 10.80 & 11.03 & 65.87 & 0.30 & 0.36 \\
$\begin{array}{l}\text { Intercropping } \\
\text { (Upland Rice }\end{array}$ & 11.93 & 10.63 & 66.47 & 0.30 & 0.36 \\
Mungbean) & & & & & \\
\hline \begin{tabular}{l} 
C.V. (\%) \\
\hline
\end{tabular} & 3.60 & 6.64 & 6.42 & 3.11 & 8.73 \\
\hline
\end{tabular}

The growth and yield of mungbean were comparable in the intercropping and monocropping systems (Tables 5 and 8). However, optimum growth and yield of the legume crop was not observed because of drought stress. Growth was stunted, leaves were chlorotic and small, and flowering was earlier than expected (Fig.2). These observations were similar to the findings of Abdel and Al-Rawi (2011) that crop phenology, leaf development, number of leaves per plant and grain yield were affected in water stressed mungbean.

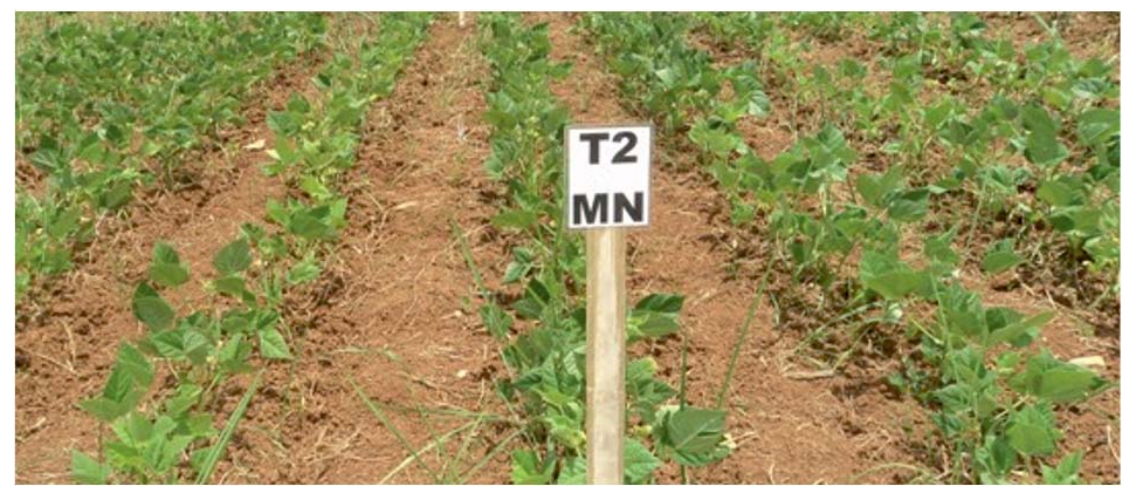

Fig.2. Water-stressed mungbean 
Evaluation of different cropping systems for marginal uplands

Pod priming was done only twice as compared to 4-5 primings under normal conditions. The grain yield was $0.22 \mathrm{t} /$ ha for mungbean alone and $0.30 \mathrm{t} /$ ha for cereals + mungbean. The yield in both cropping schemes were below the average yield of $0.70 \mathrm{t} / \mathrm{ha}$ (Ranawake et al., 2011). This suggests that mungbean is not suitable during dry season.

\section{Other parameters gathered}

The extent of the extra contribution of crop in mixtures to production per unit area has been measured in terms of land equivalent ratio (LER). It is the land area required for sole crops to produce the same yield achieved in intercropping combination (Hardwood, 1979 as cited by Armachuelo, 1987). It focuses more on the maximum utilization of the land without considering the competitive ability of the different crop components. Corn + mungbean gave an LER of 1.53 (Table 9), which means that such practice is more productive than growing corn or mungbean as monocrop. This would further mean that $53 \%$ more land would be required for mungbean and corn monocropping scheme to equalize or surpass the yield of corn + mungbean intercropping. On the other hand, growing upland rice alone was more productive than upland rice + mungbean as indicated by the LER of 0.93 (Table 9).

Area time equivalent ratio (ATER) measures the productivity and efficiency of crops in mixture in terms of utilizing both the land area and time component the crops are occupying the land. ATER value for corn + mungbean (2.19) was greater than upland rice + mungbean (0.77) because upland rice matures later than corn (Table 9) Thus, the upland rice occupied the land longer.

\section{Costand return analysis}

Results of the economic analysis revealed that only corn + mungbean obtained a profit of PhP 8,452.18per hectare (Table 10). Only this cropping system gave a net income despite of the high cost of land preparation during farm establishment. This indicates that for a newly cultivated marginal upland, the farmer should be aware of the expenses needed and the expected net return. 
Table 9. Land equivalent ratio (LER) and area time equivalent ratio (ATER) of corn mungbean and upland rice + mungbean intercropping scheme.

\begin{tabular}{lcc}
\hline \multicolumn{1}{c}{ Cropping System } & LER & ATER \\
\hline Corn Alone vs. Corn + Mungbean & 1.53 & \\
Upland Rice Alone vs. Upland Rice + Mungbean & 0.93 & \\
Corn + Mungbean & & 2.19 \\
Upland Rice + Mungbean & & 0.77 \\
\hline
\end{tabular}

Table 10.Production cost and return analysis of different cropping systems for marginal upland in Brgy. Linao, Sitio Batuan, Inopacan Leyte.

\begin{tabular}{|c|c|c|c|c|c|}
\hline \multirow[t]{2}{*}{ Treatments } & \multicolumn{2}{|c|}{$\begin{array}{l}\text { Grain } \\
\text { Yield } \\
\left(\text { tha }^{-1}\right)\end{array}$} & \multirow[t]{2}{*}{$\begin{array}{c}\text { Gross } \\
\text { Income } \\
\left(\text { PhP ha }^{-1}\right)\end{array}$} & \multirow[t]{2}{*}{$\begin{array}{l}\text { Production } \\
\text { Cost } \\
\left(\mathrm{PhP} \mathrm{ha}^{-1}\right)\end{array}$} & \multirow[t]{2}{*}{$\begin{array}{c}\text { Net } \\
\text { Income } \\
\left(\mathrm{PhP} \mathrm{ha}^{-1}\right)\end{array}$} \\
\hline & Main & Inter & & & \\
\hline $\mathrm{T}_{1}=$ Corn Alone & 2.00 & & $28,000.00$ & $39,117.82$ & $-11,117.82$ \\
\hline $\mathrm{T}_{2}=$ Mungbean Alone & 0.22 & & $15,400.00$ & $37,942.82$ & $-22,542.82$ \\
\hline $\mathrm{T}_{3}=$ Upland Rice Alone & 0.64 & & $8,960.00$ & $44,108.82$ & $-35,148.82$ \\
\hline $\mathrm{T}_{4}=$ Corn + Mungbean & 2.38 & 0.30 & $48,320.00$ & $39,867.82$ & $8,452.18$ \\
\hline $\mathrm{T}_{5}=$ Upland Rice + Mungbean & 0.52 & 0.30 & $22,280.00$ & $46,258.82$ & $-38,978.82$ \\
\hline
\end{tabular}

Market price of corn grain $=P h P 14.00 / \mathrm{kg} ;$ dried palay $=P h P 14.00 / \mathrm{kg} ;$ mungbean $=$ PhP50.00/kg

\section{CONCLUSIONS AND RECOMMENDATIONS}

Based on the results of the study, it is concluded that during dry season:

1. Corn (IPB var. 6) and upland rice (var. Zambales) can be grown during the first and second week of February under monocropping and intercropping systems in the marginal uplands of Inopacan. However, bird infestation must be controlled to minimize yield loss in upland rice production.

2. Mungbean (var. Pagasa 19) is not productive if grown as sole crop in the marginal uplands of Inopacan.

3. Intercropping corn + mungbean is more productive than corn alone, however, it is recommended to find other legume crops that could perform better than mungbean under upland condition.

4. In a newly developed marginal upland, corn + mungbean is profitable in Inopacan but higher net income cannot be achieved because of high land preparation expenses. 
Evaluation of different cropping systems for marginal uplands

It is recommended that the same crop combination should be tested during wet season to compare the crop's performance and determine the productivity and profitability of the cropping system.

\section{REFERENCES}

ABDEL C.G. and I.M. AL-RAWI. 2011. Response of mungbean (Vignaradiata) to gibberellic acid $\left(\mathrm{GA}_{3}\right)$ rates and varying irrigation frequencies. International Journal of Bioscience 1(3): pp. 85-95.

ADININGSIHJ.S and A.S. KARAMA, 1998.A Sustainable Upland Farming in Indonesia. Center for Soil and Agroclimate Research (CSAR).Agency for Agricultural Research and Development.

ARMACHUELOM.C.G. 1987.Interspecific Competition of Corn-Peanut Cropping System Integration with Ipil-ipil Hedgerow.MS. Thesis. ViSCA, Baybay, Leyte. pp. 123.

AZAM-ALI S.N., R.B. MATTHEWS, J.H. WILLIAMS and J.M. PEACOCK. 1990. Light Use, Water Uptake and Performance of Individual Components of Sorghum/groundnut intercrop. Exp. Agric. 26.pp 413-427

CANTONEROS J.A. 2008. Performance of Corn Hybrid and Peanut under Various Cropping Schemes in Association with Full Grown and Fruit Bearing Jackfruit Plantation. MS. Thesis. VSU, Baybay City.Leyte.pp

CARANDANG D.A. 1976. Integrated Research on Multiple Cropping. Technical Report, UPLB/NSDB. Integrated Research Program. pp 46

CASTILLO E.T. 2010.A Research Compedium for Marginal Uplands. Department of Environment and Natural Resources, Ecosystems Research and Development Bureau.(Online http://erdb.denr.gov.ph/ publications/others/uplandcompendium. pdf) accessed December 2, 2013

EDMEADES D.C. 2003. The Long-term Effects of Manures and Fertilizers on Soil Productivity and Quality: a review. Nutrient Cycling in Agroecosystems 66:2. pp. 165-180. 
ESCASINAS A.B. 1990. Fundamentals of Farming System. Study Guide. Visca Open University. Office of Graduate School. Visca, Baybay. Leyte. pp 35

GERPACIO R.V., J.D.LABIOS, R.V. LABIOS and E.I. DIANGKINAY. 2004. Maize in the Philippines: Production Systems, Constraints, and Research Priorities. Mexico, D.F.: CIMMYT.

INTERNATIONAL RICE RESEARCH INSTITUTE (IRRI) n.d. Rice Production and Processing (Available online at http: //irri.org/index.php.html. Accessed 23 October 2013).

LANDON J.R. 1991.Booker Tropical Soil Manual.A Handbook for Soil Survey and Agricultural Land Evaluation in the Tropics and Subtropics.Longman Scientific and Technical.John Wiley and Sons, Inc. $6053^{\text {rd }}$ Avenue. N.Y. 10158. pp. 474.

MACANDOG D.B., R.G. VISCO, E.R. ABUCAY and L.E. GARCIA. 2006. Alternative Land Use Options for Philippine Grassland: A Bioeconomic Modeling Approach Using the WaNuLCAS Model. Proceedings of the International Symposium Towards Sustainable Livelihoods and Ecosystems in Mountainous Regions. Chiang Mai, Thailand.

PCARR 1976.The Philippine Recommends for Integrated Farming System. Los Banos, Laguna. pp. 92.

RANAWAKE A.L., U.G.S. AMARASINGHA. W.D.R.J. RODRIGO, U.T.D. RODRIGO and N.DAHANAYAKA.2011. Effect of Water Stress on Growth and Yield of Mungbean(Vignaradiata). Tropical Agricultural Research and Extension. 14 (4):2011

TEJADA S.Q., R.B. CARATING, J. MANGUERA, I. SAMALCA, and L.R. RETAMAR. Land degradation and desertification assessment in the Philippines. Department of Agriculture, Bureau of Soils and Water Management. Presented during the Regional Training Workshop on Land Degradation and Desertification Assessment: Accessed on 23 April 2014 http.fao.org/nr/lada/index.php. 